\title{
Problems and interpretations of Schopenhauer's World as Will and Representation ${ }^{1}$
}

\author{
Problemas e interpretações de O mundo como vontade e representação de \\ Schopenhauer
}

\author{
Jens Lemanski', Daniel Schubbe"
}

\begin{abstract}
In this paper we present an overview of the current interpretations of the first volume of Arthur Schopenhauer's main work The World as Will and Representation (W I) and discuss their problems. We discuss four issues, which in our opinion must clarify a current interpretation implicitly or explicitly, if it claims to be an interpretation of the whole book: (1) What does Schopenhauer mean by the fact that his work shares only one (single) thought? (2) How are the individual books of W I related? (3) Do we have to read Schopenhauer's W I as a normative guide to the denial of will-to-live or as a neutral description of the world? (4) Do the often discussed contradictions and aporias within the book follow a plan or are they errors of thought?
\end{abstract}

Keywords: System; World; Normative ethics; Descriptive ethics; Hermeneutics; Contradictions

Resumo: Neste artigo, apresentamos uma visão geral das interpretações atuais do Tomo I da obra principal de Arthur Schopenhauer, $\mathrm{O}$ mundo como vontade e representação (W I), e analisamos seus problemas. Discutimos quatro questões, que em nossa opinião podem lançar luz a uma interpretação atual, implícita ou explicitamente, no caso de se pretender uma interpretação do livro como um todo: (1) O que Schopenhauer quer dizer com o fato de que seu trabalho exibe apenas um (único) pensamento? (2) Como os livros individuais de WI estão relacionados? (3) Precisamos ler a obra de Schopenhauer como um guia normativo para a negação da vontade de vida, ou como uma descrição neutra do mundo? (4) As contradições e aporias frequentemente discutidas no interior do livro seguem um plano ou são equívocos de pensamento?

Palavras-chave: Sistema; Mundo; Ética normativa; Ética descritiva; Hermenêutica; Contradições

\section{Preface}

Not only the content and argumentation of the first volume of Schopenhauer's main work The World as Will and Representation (W I) are decisive for its understanding, but also its structure, organisation, form of argumentation and systematization. However, there is no consensus in research regarding the interpretation of its structure and content. In essence, the discussions revolve around four questions or areas of conflict: (1) What does Schopenhauer mean by the fact that his work shares only one (single) thought? What role

\footnotetext{
Privatdozent (Adjunct Professor) at Institut for Philosophy, FernUniversität in Hagen, Germany. jenslemanski@gmail.com "Wissenschaftlicher Mitarbeiter (Lecturer) at Faculty for Humanities and Social Sciences FernUniversität in Hagen Germany.daniel.schubbe@fernuni-hagen.de

Originally published in German by J.B. Metzler, Stuttgart (c) Springer-Verlag GmbH Deutschland, ein Teil von Springer Nature 2018: LEMANSKI, Jens; SCHUBBE, Daniel. Konzeptionelle Probleme und Interpretationsansätze der Welt als Wille und Vorstellung. In: Daniel Schubbe; Matthias Koßler (Ed.). Schopenhauer-Handbuch. Leben - Werk - Wirkung. $2^{\text {nd }}$ edition. Stuttgart: Metzler, 2018, pp. 43-51.
} 
does this thought play in his work? (2) How are the individual books of W I related? In an architectural, systematic, or organic way? (3) How does the work relate to the reader, on the one hand, and to the world, on the other? Normative in relation to the reader or only descriptive in relation to the world? (4) What about the often discussed contradictions and aporias in the main work? Do they follow a plan or are they errors of thought?

The following sections will outline the different positions that have emerged in the discussions and give an overview of some of the old but still unsolved problems of Schopenhauer research. In section 1, we will first present the problems associated with Schopenhauer's assertion that his work contains only one single thought. Section 2 will discuss various interpretations that address the question of whether W I is an architecture, a system or an organism. In section 3, three different interpretational directions are presented to show how Schopenhauer's major work can be read, i.e. as either a normative, axiological or descriptive system. Finally, in section 4, we will deal with the problem that Schopenhauer's work contains various aporias and contradictions.

The overall aim of this paper is to present the main positions and opinions found in research. It is therefore not the aim of this paper to convince the reader of our own opinion, but to introduce him to various positions of interpretation. However, since we have expressed our own opinions in various research papers, they are presented as a research position alongside the opposing opinions. Finally, this paper is only motivated by an overarching thesis, namely that one cannot interpret W I without (explicitly or implicitly, consciously or unconsciously) taking a position on the issues at hand which are presented in this article.

\section{The one (single) thought}

Already in the second sentence of the preface of W I there is a phrase that has provoked a broad controversy in research: "What is to be imparted by it [the book; J. L./D. S.] is a single thought." (W I, Preface to the first edition, p. xx) Schopenhauer claims that his work only articulates one thought. But this thought can only be communicated by dividing it into four parts. And these four parts refer to the "books" of W I's first volume. However, according to Schopenhauer, "we have specially to guard against losing sight, among the details that must needs be discussed, of the principal thought to which they belong, and of the progress of the exposition as a whole" (W I, Preface to the first edition, p. xxi; cf. also HN I, p. 386f). (In the following, we do not distinguish between "one thought", "single thought", and "one single thought".)

Schopenhauer does not state anywhere else an explicit formulation that shows exactly what the one thought is ${ }^{2}$. Thus, in matters of interpretation, the attempt to identify this single thought has been surrounded in controversy. In this context it could not be unimportant, as Rudolf Malter notes, to distinguish between sentences and thoughts. For the one thought is "only present in sentences (consisting of abstract ideas), although it is

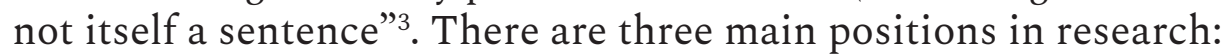

1) A common interpretation understands the one thought as a kind of extract of the central topics of WWR, similar to a concise summary of the essential thoughts of the work. This is how Rudolf Malter understands the one thought with the help of the proposition: "the world is the self-knowledge of the will" (W I, § 71, p. 410). This sentence can be traced back to a remark, which can be found in Schopenhauer's manuscripts of 1817 ("My whole philosophy can be summed up in one expression: the

\footnotetext{
${ }^{2}$ Cf. ATWELL, Schopenhauer on the Character of the World, p. 18; JANAWAY, Introduction, p. 4. 
world is the self-knowledge of the will” (HN I, p. 462)) and finally - as quoted above also found its way into the main work. Wolfang Weimer extends this definition of one thought by introducing the following addition: "The world is the self-knowledge of the will of its sufferings. This suffering can be eliminated in various stages" ". Volker Spierling ${ }^{6}$ sees the one thought expressed in the formulation that "this world in which we live and have our being is, by its whole nature, through and through will, and at the same time through and through representation" (W I, § 29, p. 162). Jochem Hennigfeld sees another candidate for the one thought in phrase that he interprets as a principle of Schopenhauer's whole system: "The will, as the thing-in-itself, constitutes the inner, true, and indestructible nature of man [...]” (W II, chap. 19, p. 201).

John Atwell notes that the decisive insights of the third and fourth book must be taken into account if the one thought is to be formulated ${ }^{8}$. He therefore discusses several proposals and their consequences. Finally he comes to the formulation: "The double-sided world is the striving of the will to become fully conscious of itself so that, recoiling in horror at its inner, self-divisive nature, it may annul itself and thereby its self-affirmation, and then reach salvation". As Atwell's formulations illustrates, the first interpretation is characterised by the attempt to capture the one thought by means of the content's summary. With this first interpretation, however, it is questionable to what extent these text passages of Schopenhauer's work can be integrated into the formulation. This emphasizes the fact that it is necessary to distinguish between the communicated thoughts (as parts of the one thought) and the one thought itself (cf. HN I, p. 387). It is therefore necessary to ask whether the premises of the mentioned authors are correct. These premises are, on the one hand, that one thought is abstract and directly communicable and, on the other, that one thought consists in the combination of the various passages of Schopenhauer's work ${ }^{10}$.

2) According to another interpretation, the communication of the one single thought is also a central objective of W I, but this interpretation denies the possibility of combining thoughts into one expressed in one sentence or of extracting the one thought from various text passages of W I. Rather, Schopenhauer's work itself refers to the one thought: the work is thus a performative thread that allows the one thought to exist only in the active thinking of the reader. For example, Matthias Koßler emphasizes with regard to the "Thebenmetapher" (see below) that the one thought "is to be found in the centre of the intersecting but not converging directions" ${ }^{11}$. Daniel Schubbe speaks of an explicit performative interpretation of the one thought. Consequently, one thought does not vouch for a certain content, but rather for the unity of the work itself. Therefore, the one thought should be understood as "the commonality of the different perspectives or areas of reality"12. One idea is thus, at the theoretical level, a kind of parallel concept to the world in which the individual contents are also present together. At the theoretical level, the one thought is thus a kind of a parallel concept to the world in which the individual contents of Schopenhauer's work are also present together.

3) A third interpretation does not argue that the decisive passage with which Schopenhauer wants to determine the one thought is in the preface of W I. Rather, it argued that the relevant passage comes at the end of $\S 15$. On the one hand, the "one single

\footnotetext{
WEIMER, Ist eine Deutung der Welt als Wille und Vorstellung heute noch möglich?, p. 17.

${ }^{6}$ Cf. SPIERLING, Arthur Schopenhauer, p. 63.

7 HENNIGFELD, Metaphysik und Anthropologie des Willens, p. 465.

${ }^{8}$ Cf. ATWELL, Schopenhauer on the Character of the World, p. 30; JANAWAY, Introduction, p. 5.

ATWELL, Schopenhauer on the Character of the World, p. 31.

${ }^{10} \mathrm{Cf}$. SCHUBBE, Philosophie des Zwischen, p. 51f.

${ }^{11}$ KOSSLER, Schopenhauer als Philosoph des Übergangs, p. 375.

${ }^{12}$ SCHUBBE, Philosophie des Zwischen, p. 195.
} 
thought" is only a traditional idea that was taken over by Schopenhauer from history of ideas: Descartes, Spinoza, Jacobi and Fichte had already used the expression of a "one single thought" in a similar way ${ }^{13}$. On the other hand, Schopenhauer uses this expression in the preface of W I only to answer the question of how to read the book. The actual definition of one thought and thus the objective of W I can only be found in $\S 15$ : Schopenhauer explains there that the task of his philosophy is "to present to rational knowledge the whole manifold of the world in general, according to its nature, condensed and summarized into a few abstract concepts” (W I, § 15, p. 82). As with the parallel passage in the fourth book (cf. W I, § 68, p. 383-4), Schopenhauer refers to Francis Bacon and thus supports an empirical approach ${ }^{14}$. The task of this early modern and enlightened line of tradition beginning with Bacon and continuing to Schopenhauer is to replace the Bible with the philosophical book, which shall explain the whole world rationally and on the basis of empirical evidence ${ }^{15}$.

The objective, i. e. a "complete recapitulation, so to speak, a reflection of the world in abstract concepts” (W I, $\S 15$, p. 83) becomes apparent in an analogy: If, as Schopenhauer says, the "ground of knowledge" is "immediately the world itself in its entirety" (W I, § 15, p. 82-3) and this is reflected by W I, then "world" is the highest concept (conceptus summus) of W I, which encompasses all other concepts of the book (conceptus inferiores). Thus, the book about the world, the W I, behaves like the real world, which also encompasses all other entities ${ }^{16}$.

Similarly, for Arthur Hübscher, the title "The world as will and representation" brings the one thought "to a short formula", it "comes, in each line at present, in four books as well as in four symphonic movements to the universal unfolding" ${ }^{17}$. If you look at the last sentences of $\S 15$, you will find a combination of the first two arguments: Will and representation (including the concepts contained therein) are all sub-concepts of the highest concept "world". Every concept is included in the comprehension of the concept "world". As the highest concept, therefore, the concept of the world mediates between the dichotomies; "[t]heir harmony with one another, by virtue of which they flow together even into the unity of one thought [...] springs from the harmony and unity of the world of perception itself” (W I, § 15, p. 83).

\title{
Architectonics, system or organism?
}

Another controversy concerns the question of how to understand the context of the four books of W I. This controversy focuses on the three metaphors "architectonics", "system" and "organism" that emerge in the context of considering the 'one single thought':

\begin{abstract}
A system of thought must always have an architectonic connexion or coherence, that is to say, a connexion in which one part always supports the other, though not the latter the former; in which the foundation-stone carries all the parts without being carried by them; and in which the pinnacle is upheld without upholding. On the other hand, a single thought, however comprehensive, must preserve the most perfect unity. If, all the same, it can be split up into parts for the purpose of being communicated, then the connexion of these parts must once more be organic, i.e., of such a kind that every part supports the whole just as much as it is supported by the whole [...] (W I, Preface to the first edition, p. xx).
\end{abstract}

There is a controversy as to whether Schopenhauer either uses the term 'system' synonymously to 'architectonically' and thus as a counter term to 'organically'18 or whether

\footnotetext{
${ }^{13}$ Cf. LEMANSKI, Christentum im Atheismus, p. 316; KOSSLER, Schopenhauer als Philosoph des Übergangs.

${ }^{14} \mathrm{Cf}$. KOSSLER, Empirische Ethik und christliche Moral.

${ }^{15} \mathrm{Cf}$. BLUMENBERG, Die Lesbarkeit der Welt.

${ }^{16}$ Cf. LEMANSKI, Schopenhauer's World.

17 HÜBSCHER, Schopenhauer, p. 69.

${ }^{18}$ Cf. SCHUBBE, Philosophie des Zwischen, p. 50.
} 
he uses 'system' as a general term in relation to the two contrary sub-terms 'architectonically' and 'organically' ${ }^{19}$. However, it can be said that in both cases 'architectonically' is the opposite metaphor to 'organic'. Therefore, we will only reference the latter dichotomy in the following.

In general, it can be said that Schopenhauer explicitly does not want his work to be understood as a form of architectonics, but rather as an organism. The difference: whereas, according to Schopenhauer, architectonics is linearly constructed, in an organism each part holds the other. Schopenhauer understands his work in such a way that the last part holds the first one as well as the first part holds the last one. As Schopenhauer stated, the division of his work into four parts is thus not a matter of substance, but it is a problem of communication: Since a book must have a first and last sentence, there is no other way between both than a linear and architectural one. But this way should not be confused with the thought itself. According to Schopenhauer, this inevitably leads to a contradiction between content and form (cf. W I, Preface to the first edition, p. xxi), which can be corrected by reading the book (at least) twice.

However, recent research is discussing whether the contradiction between content and form does not have broader consequences than Schopenhauer is willing to admit. For example, Martin Booms ${ }^{20}$ emphasizes that Schopenhauer makes two different statements regarding the problematic nature of how his system begins: On the one hand, one can focus on Schopenhauer's famous 'Analogy of Theben' from 1841 (cf. E, Preface to the first edition, p. 6), often also referred to as the 'metaphor of Theben'). According to this analogy, the entry into Schopenhauer's philosophy is arbitrary, since one can come from anywhere of his system to the center of attention. On the other hand, this is the idea - formulated in the second volume of the Parerga and Paralipomena - that "every philosophy must commence with examination of the cognitive faculty, its form and laws, as well as their validity and limitations" (P II, $\S$ 21, p. 21). According to Booms, this leads to antinomies at the very beginning. He speaks of an 'antinomy of method', since one position contradicts the other. Moreover, the form determinates the content in such a way that the beginning of W I with the theory of knowledge (which he interprets as a transcendentalism) seems like the introduction of a dominant theory. The epistemology has thus a leading position in W I. This makes Schopenhauer's whole philosophy a transcendental one. The primary position of epistemology thus becomes the fundament of the whole system. For Booms, the problem of how W I begins contributes decisively to the question of how to characterize the work as a whole.

Schubbe also deals with the interdependence of form and content in W I. In contrast to Booms, he asks first of all what Schopenhauer wants to define as content and form ${ }^{21}$. On the one hand, Schubbe emphasizes the descriptive character of Schopenhauer's epistemology. On the other, he explains that the beginning of the book on epistemology has only a didactic sense. (This didactic sense was made explicit by Schopenhauer, but in Booms it was neglected). By referring to this contrast he tries to show that epistemology is neither the foundation of the rest nor the determination of the form in Schopenhauer. Rather, the overall form of the whole W I has to be considered by interpreting Schopenhauer's philosophy. In other words, the content cannot be abstracted from the form. Thus Schubbe distinguishes between the performative-indirect thought and many direct thoughts in the work. On the basis of this distinction, the Theben analogy and the question of the beginning are simply on different levels of explanation: The Theben analogy refers to the one thought. The didactically understood question of the beginning, on the other hand, refers to the direct thoughts. And it is through this that the one thought is invoked in the best case.

\footnotetext{
${ }^{19}$ Cf. STRUB, Weltzusammenhänge, p. 106; BLOCH, Leipziger Vorlesungen zur Geschichte der Philosophie, p. 369.

${ }^{20} \mathrm{Cf}$. BOOMS, Aporie und Subjekt, pp. 141-146.

${ }^{21}$ Cf. SCHUBBE, Philosophie des Zwischen, pp. 25-31.
} 
But let us come back to the question of which arguments speak in favour of the metaphor of architectonics (1) or of organism (2).

1) Schopenhauer himself had supported the metaphor of organism. Nevertheless, one finds a) in his own work (cf. e.g. W II, chap. 24, 360) and b) in research an approach to the metaphor of architectonics.

a) Most of the general concepts in W I form a structure that corresponds to the tree of porphyry, which Schopenhauer himself describes in his logic (cf. e.g. W II, chap. 6, p. 64); VN I, p. 259-276). This tree structure extends from the most abstract concepts such as 'world' to very concrete concepts such as for example the definitions of 'laughter', 'wit' and 'foolishness' (cf. W I, § 13, p. 59-60). One could now imagine that Schopenhauer derives this whole structure from the semantics of the most general concept, i.e. 'world'. Despite the metaphor of architectonics, however, Schopenhauer criticises a method in early modern philosophy that deduces only from general concepts and principles (cf. W I, § 15, p. 82). He found examples for such a method in early modern philosophy, namely in Spinoza or Wolff ${ }^{22}$. Insights can be derived from this criticism: The conceptual structure of W I is one of the major achievements of the work, but it is only an overall result and not the method of W I. That may be one of the reasons why this conceptual structure has not yet been investigated in research ${ }^{23}$.

b) Research, on the other hand, has so far focused more intensively on the structure of the work's topics. On the one hand, this is important for linearity, which needs to be examined in more detail. On the other hand, the topic structure is partly important for the metaphor of architectonics, since it determines the position of certain topics within the work: some people claim that the beginning of W I is not simply arbitrary, since the epistemology is intended to "avoid any transcendent dogmatism"24. Or in other words, because it "opens the procedural process as a part of it and represents it" 25 . The last paragraphs of W I also seem to be firmly cemented for many artists. Particularly relevant for this position was Franz Rosenzweig's thesis on Schopenhauer's "system-generated saint in the conclusion", i.e. the last paragraphs of W I. This archetypus of a saint "closed the systemic arch, really closed it as a keystone, not as an ethical piece of jewellery or as an appendix supplemented"26. Eduard von Hartmann also speaks of an emphasis on 'nothing', which "has been described repeatedly and emphatically by Schopenhauer as the summit not only of his ethics, but also of his entire philosophical system" ${ }^{27}$. According to Hans Zint, Schopenhauer's philosophy of religion, the sacred and the nothing, thus become the "luminous finale of his whole philosophy"28. In this respect, Klamp also points out that the third book can only be a "preschool" for the "impressive final parts" of the fourth book ${ }^{29}$. For most interpreters, the fixed thematic arrangement from epistemology to 'mystical ontology' is accompanied by a linear structure within W I.

2) Both a) Schopenhauer himself in many places and b) more and more researchers in recent times have adopted the metaphor of organism for his work.

a) Schopenhauer himself emphasizes: "According as we consider under different aspects this one thought that is to be imparted, it appears as what has been called metaphysics, what has been called ethics, and what has been called aesthetics [...]” (W I, Preface to the first edition, p. xx).

\footnotetext{
${ }^{22}$ Cf. STRUB, Weltzusammenhänge, p. $106 f$.

${ }^{23}$ Cf. LEMANSKI, Schopenhauer's World.

24 SPIERLING, Arthur Schopenhauer, p. 49

${ }^{25}$ MALTER, Arthur Schopenhauer, p. 53.

${ }^{26}$ ROSENZWEIG, Stern der Erlösung, p. $8 f$.

27 HARTMANN, Phänomenologie des sittlichen Bewusstsein, p. 54.

28 ZINT, Das Religiöse bei Schopenhauer, p. 63.

${ }^{29}$ KLAMP, Die Architektonik im Gesamtwerk Schopenhauers, p. 83.
} 
b) For this reason, as Robert Jan Berg claims, is "the entry into the organism basically arbitrary" ${ }^{30}$. Although Schopenhauer developed the world as will from the world as representation in the first book of W I, the reader could just as well start with the second book. For there, Schopenhauer also explains the world as representation from the world as will and thus the two books complement each other. The priority of the 'world' is determined only by the methodology of the certain topic, i.e. epistemology or natural philosophy. The arbitrary position of the last paragraphs in W I is also illustrated by the new paragraphs in Schopenhauer's lectures. In these lectures, Schopenhauer does not end with a paragraph on "Nothingness", but with a metaphilosophical theme (cf. VN IV, p. 271ff.). Within the organic reading, an alternative version of $\mathrm{W}$ I would be conceivable, which does not end with the denial but with the affirmation of the will.

\section{W I: A normative, axiological or descriptive System?}

By looking at the end of W I early on in research and by defining it architecturally, the linear interpretation has been combined with a normative one: since Schopenhauer describes the ascetic and his escape into nothingness at the end of his work, it was obvious to many interpreters that the author of W I would "expect his reader to deny the will to live"31. That is why Paul Deussen also explains that Schopenhauer's ethics "have an imperative form. For Schopenhauer, it lies in the fact that he confronts the denial of the will to live with the affirmation of the will, whereas the former one is throughout the higher, better one"32.

However, this quotation covers a difference which, according to other interpreters, can point to an "intermediate path" between a normative or descriptive interpretation: it is quite possible to concede that Schopenhauer wants his work to be descriptively understood, but nevertheless grants the world overcomer a more valuable and higher status than the one who affirms his life. Such an axiological interpretation is evaluative, but not prescriptive. A descriptive reading is neither normative nor axiological. Since the three interpretations are most evident in the interpretation of Schopenhauer's denial of the will to live, one can use the following definitions:

1) Normative interpretation: Schopenhauer wants to convince his reader of the denial of the will to live, so that they put it into practice.

2) Axiological interpretation: Schopenhauer only describes the denial of will to live, but evaluates it as better in comparison to the affirmation of the will to live.

3) Descriptive interpretation: Schopenhauer only describes the denial and affirmation of the will to live as being equivalent.

The word 'Soteriology', which is not used by Schopenhauer but has been intensively discussed in research, falls into the field of the denial of the will and can therefore (1) be interpreted normatively, (2) axiologically or (3) descriptively. In principle, however, all three interpretations also diverge on other issues, such as the interpretation of idealism and empiricism in the first book of W I.

Malter could be counted among the representatives of an axiological interpretation of soteriology, according to which the main work is to be understood as a process of liberation described by the author: "[t]he formulaic naming of the one thought indicates a process: the process in which the liberation of the subject from its negative state takes place" 33 .

\footnotetext{
${ }^{30}$ BERG, Objektiver Idealismus und Voluntarismus, p. 99; similar to WILHELM, Zwischen Allwissenheitslehre und Verzweiflung, p. 10.

${ }^{31}$ WEIGELT, Zur Geschichte der neueren Philosophie, p. 156.

${ }^{32}$ DEUSSEN, Allgemeine Geschichte der Philosophie, p. 555.

${ }^{33}$ MALTER, Arthur Schopenhaver, p. 52.
} 
According to Malter, the progress is being made through various crises to salvation:

\begin{abstract}
Schopenhauer's philosophy can only be described as a Soteriology [...], because the liberating and redeeming moment was originally created in the subject. To retrace how the activation of this moment comes about and how the will (although the subject is no longer determined by its own substantiality) no longer determines the subject is the goal to which the Schopenhauerian system is directed, with the help of to the transcendentalism that guides $i^{34}$.
\end{abstract}

This shows that the architectural connection between 'transcendentalism' (guiding principle) and 'theory of redemption' (goal) leads to a linear interpretation of the work. Architectural context and linear method are also linked in the interpretation of Alfred Schmidt: "Resignation is the difficult to describe basic mood into which Schopenhauer's thinking flows" 35 . The linearity and normativity can thus be interpreted from the style, the context of the last paragraphs and from Schopenhauer's later self-interpretations. Complementary to normative soteriology in ethics, which is particularly discussed in German-speaking research (keyword: 'Erlösung durch Erkenntnis', i.e. salvation through knowledge), a normative doctrine of liberation in aesthetics is discussed in Spanish and especially in English-speaking research (keyword: 'Art as liberation').

Representatives of a mere descriptive interpretation, on the other hand, refer primarily to the opening paragraphs of the fourth book of W I, in which Schopenhauer explains that his ethics also remains only theoretical and does not recommend prescribing anything (cf. W I, § 53, p. 271). For Koßler, this is the reason to speak of an "empirical ethics" and to emphasize that Schopenhauer also understands "ethics not prescriptively, but rather descriptively" ${ }^{36}$. Nicoletta de Cian and Marco Segala assert that Schopenhauer scholarship amongst English-speaking academics in particular has conjured up a simplified and distorted history of interpretation and reception. Schopenhauer's main goal is merely the "discovery of what the world is, disclosure of the world's essence" 37.

In this context, Jens Lemanski tries to show that the linear-normative interpretation, which interprets W I in the German-speaking world as a negative, pessimistic and life negating work, was itself favored by Schopenhauer's late writings and revisions. These approaches were established in the history of philosophy by Mainländer's, Hartmann's and especially Nietzsche's misinterpretations of Schopenhauer. According to Lemanski, this becomes obvious in the so-called "Weigelt-Becker controversy", in which Schopenhauer and his closest scholars defended themselves against the linear-normative interpretation which was popular in 1850s. Schopenhauer and his scholars found their way back to the clarity of the first edition of W I, in which the reflection of the world was more prominent than in the late work ${ }^{38}$.

The linear-soteriological approach finds a further counterpart in a morphological interpretation ${ }^{39}$. According to this interpretation, the forms of knowledge and humanworld-relationships, which are explicit in the four books of W I, are to be regarded as of equal importance in terms of epistemology and ontology ("Four-aspects doctrine" compared to a "Two-aspects-doctrine" or "Two-worlds-doctrine" ${ }^{40}$ ).

However, it is possible that the issue of a purely descriptive reading of W I may have to be limited by another side than that of the normative interpretation: since Schopenhauer does not only refer to a description of the world in relation to his metaphysics, but also to its

\footnotetext{
${ }^{4}$ Ibid., p. 55.

${ }^{35}$ SCHMIDT, Die Wahrheit im Gewande der Lüge, p. 75.

${ }^{36}$ KOSSLER, Empirische Ethik und christliche Moral, p. 434.

${ }^{37}$ DE CIAN; SEGALA, What is Will?, p. 31.

${ }^{38} \mathrm{Cf}$. LEMANSKI, The Denial of the Will-to-Live, pp. 153-161.

${ }^{39} \mathrm{Cf}$. SCHUBBE, Philosophie des Zwischen; SCHUBBE, Formen der (Er-)Kenntnis.

${ }^{40}$ Cf. SCHUBBE, Philosophie des Zwischen, p. 195 (note 554).
} 
interpretation, the question here arises as to whether "description" and "interpretation" are mutually exclusive terms, or whether they referring to each other. These questions are mainly discussed in the context of Schopenhauer's phenomenology and hermeneutics.

\section{Contradictions and aporias in W I}

Very early on - namely in 1819 by an anonymous reviewer - Schopenhauer's interpreters drew attention to aporias or contradictions in W I. This discussion is still present in Schopenhauer scholarship today. It is noticeable that there has been no consensus, either on the matter of which passages ought to be recognized as such, nor as to the terminology which should be used in referring to them. For example, there is use of such terms as 'contradiction', 'aporia', 'antinomy' and 'circularity'. Various assessments and evaluations of the problem can be found which roughly divide into four groups ${ }^{41}$ :

While some interpreters try to expose the accusations of 'contradictions' aimed at Schopenhauer as symptoms of the accusers' own misunderstanding ${ }^{42}$, others read the 'contradictions' as evincing a failed theory ${ }^{43}$. While these two groups consider the 'contradictions' to be uniformly negative or problematic despite their divergences, a third group can be identified that sees them as a constitutive, positive component of Schopenhauer's thinking ${ }^{44}$. A fourth group is formed by those who see the conceptual contradictions in W I as a reflection of the real contradictions in the world ${ }^{45}$.

Recent research is essentially influenced by Volker Spierling's dissertation on 'Schopenhauer's transcendental idealistic self-conception' of 1977. With this publication, Spierling has started a discussion in research and has continued to clarify and modify his thesis. His approach allows us to take a look at the overall concept of W I. Spierling draws particular attention to recurring passages in Schopenhauer's oeuvre, wherein Schopenhauer speaks of the fact that every thought in philosophy would be one-sided if it were not compensated by a change of perspective (cf. e.g. $\mathrm{P}$ II, § 27, p. 34).

With this approach, Spierling tries to show that Schopenhauer's work includes such a form of compensation at three crucial points. These three so-called "Copernican turnarounds" allow the contradictions to be methodologically understood as a "change of standpoint" in the sense of a "forgotten dialectic" 46 . By the three "turnarounds" Spierling means (1) the change between materialism and idealism, (2) the change between metaphysical and hermeneutic contemplation of the thing in itself and (3) the change between affirmation and denial of the will to live. These are also conceptual figures in the structure of W I. For Spierling, the constitutive-positive use of the turnarounds is that they prevent an absolute standpoint. Schopenhauer is a philosopher who "reflects prudently, who methodically keeps in mind the difference between concept and matter, and who stops the a priori/idealistic thinking about identity" ${ }^{47}$.

Following the discussion of 'forgotten dialectics' and on the basis of

\footnotetext{
${ }^{41}$ For a compilation of authors who have commented on the topic, see MALTER, Arthur Schopenhauer, p. 48 (note 25); for the following systematization, cf. also BOOMS, Aporie und Subjekt, $23 f$.

42 E.g. HÜBSCHER, Denker gegen den Strom, pp. 254-265.

${ }^{43}$ E.g. BOOMS, Aporie und Subjekt; HÖSLE, Zum Verhältnis von Metaphysik des Lebendigen und allgemeiner Metaphysik, p. 78.

${ }^{44}$ Cf. e.g. SPIERLING, Arthur Schopenhauer, pp. 223-240; SCHUBBE, Philosophie des Zwischen.

${ }^{45}$ Cf. HAUCKE, Leben und Leiden; LEMANSKI, The Denial of the Will-to-Live, p. $170 \mathrm{ff}$.

${ }^{46}$ Part of the subtitle of SPIERLING, Schopenhauers transzendentalidealistisches Selbstmißverständnis

47 SPIERLING, Arthur Schopenhauer, p. 240.
} 
a comparison with Hegel's Phenomenology of Spirit, Koßler had attempted to demonstrate an implicit speculative-dialectic development in W I, which culminates in the "experience of character" 48 . More recently, the problem of aporia has been addressed, in particular by Booms, Kai Haucke and Schubbe ${ }^{49}$. Martin Booms ${ }^{50}$ radicalizes Rudolf Malter's transcendentalist reading by combining the various transcendental levels that Malter identified in Schopenhauer's work into a transcendentalism. However, Schopenhauer's aporias are viewed pejoratively by Booms. In his opinion, Schopenhauer presents a "fragile" transcendentalism that results from a misunderstanding of Kant's philosophy.

A false conception of transcendentalism in the first book leads to an aporia between subjectivist and materialist aspects. After Booms, the three following books of the main work attempted nothing more than to solve the aporia of the first book. But since the error repeats itself at every level, each book generates a new attempt until the work finally rebels against itself and ends in nothingness.

The second attempt to approach the aporias in Schopenhauer's main work in the sense of an overall interpretation is that of Kai Haucke ${ }^{51}$. Haucke tries to show that the basic aporia in Schopenhauer is to be found in his pessimism. This can only be understood if one takes into account its two components, namely maximalism and activism: excessive expectations combined with the claim to be able to achieve them. Precisely because this combination cannot succeed in practice, Schopenhauer's work leads to a turnaround from omnipotence to powerlessness. The individual aporias result from this turnaround. The aporias get their meaning in the "logic of wishing" 52 presented by pessimism.

Following Spierling, Schubbe tries to give the aporias a systematic status ${ }^{53}$. At the centre of his interpretation is the attempt to read Schopenhauer's philosophy not from the poles explicated in the individual books (subject, object; self-confidence/ body, thing in itself; pure subject of recognition, idea; compassionate, suffering) but from the relations between these poles: correlation, analogy, contemplation and compassion. The focus is thus on a 'between', out of which the individual poles arise. Finally, the aporias show themselves as figures which are supposed to make the 'between' obvious. By pointing out the limits of the respective positions, the aporias point beyond these limits to an area which cannot be clarified linguistically or propositionally - or, if so, only to a limited extent. Similarly to Spierling, the aporia become part of the formal explication of the work.

\section{References}

ATWELL, John. Schopenhauer on the Character of the World: The Metaphysics of Will. Berkeley: University of California Press, 1995.

BERG, Robert Jan. Objektiver Idealismus und Voluntarismus in der Metaphysik Schellings und Schopenhauers. Würzburg: Königshausen \& Neumann, 2003.

BERNARDY, Jörg; SCHUBBE, Daniel. Aktuelle Ansätze und Themen der Schopenhauer-Forschung. Allgemeine Zeitschrift für Philosophie, Stuttgart-Bad Cannstatt, v. 36, n. 2, 2011, pp. 238-256.

\footnotetext{
48 KOSSLER, Substantielles Wissen und subjektives Handeln; cf. KOSSLER, Die Philosophie Schopenhauers als Erfahrung des Charakters.

${ }^{49} \mathrm{Cf}$. the following remarks in BERNARDY; SCHUBBE, Aktuelle Ansätze und Themen der Schopenhauer-Forschung, p. 250ff.)

${ }^{50} \mathrm{Cf}$. BOOMS, Aporie und Subjekt.

${ }^{51}$ Cf. HAUCKE, Leben und Leiden.

52 Ibid., p. 109.

${ }^{53}$ Cf. SCHUBBE, Philosophie des Zwischen.
} 
BOOMS, Martin. Aporie und Subjekt. Die erkenntnistheoretische Entfaltungslogik der Philosophie Schopenhauers. Würzburg: Königshausen \& Neumann, 2003.

BLOCH, Ernst. Leipziger Vorlesungen zur Geschichte der Philosophie (1950-1956), Vol. 4. Frankfurt am Main: Suhrkamp, 1985.

BLUMENBERG, Hans. Die Lesbarkeit der Welt. Frankfurt am Main: Suhrkamp, 1986.

DE CIAN, Nicoletta; SEGALA, Marco. What is Will? Schopenhauer-Jahrbuch, Würzburg, v. 83, 2002, pp. 3-43.

DEUSSEN, Paul. Allgemeine Geschichte der Philosophie mit besonderer Berücksichtigung der Religionen. Vol. II/3. Leipzig: Brockhaus, 1917.

HARTMANN, Eduard von. Phänomenologie des sittlichen Bewusstseins. Eine Entwickelung seiner mannigfaltigen Gestalten in ihren inneren Zusammenhange. $3^{\text {rd }}$ edition. Berlin: Wegweiser-Verlag, 1924.

HAUCKE, Kai. Leben und Leiden. Zur Aktualität und Einheit der schopenhauerschen Philosophie. Berlin: Parerga, 2007.

HENNIGFELD, Jochem. Metaphysik und Anthropologie des Willens. Methodische Anmerkungen zur Freiheitsschrift und zur Welt als Wille und Vorstellung. In: Lore Hühn (Ed.). Die Ethik Arthur Schopenhauers im Ausgang vom Deutschen Idealismus. (Fichte/Schelling). Würzburg: Ergon, 2006, pp. 459-472.

HÖSLE, Vittorio. Zum Verhältnis von Metaphysik des Lebendigen und allgemeiner Metaphysik. Betrachtungen in kritischem Anschluss an Schopenhauer. In: Vittorio Hösle (Ed.). Metaphysik. Herausforderungen und Möglichkeiten. Stuttgart-Bad Cannstatt: Frommann-Holzboog, 2002, pp. 59-97.

HÜBSCHER, Arthur. Denker gegen den Strom. Schopenhauer: Gestern - Heute - Morgen. Bonn: Bouvier, 1988.

HÜBSCHER, Arthur. Schopenhauer. Biographie eines Weltbildes. Stuttgart: Reclam, 1952.

JANAWAY, Christopher: Introduction. In: Christopher Janaway (Ed.). The Cambridge Companion to Schopenhauer. Cambridge: Cambridge University Press, 1999, pp. 1-17.

KLAMP, Gerhard. Die Architektonik im Gesamtwerk Schopenhauers. Schopenhauer-Jahrbuch, Würzburg, v. 41, 1960, pp. 82-97.

KOSSLER, Matthias. Substantielles Wissen und subjektives Handeln, dargestellt in einem Vergleich von Hegel und Schopenhauer. Frankfurt am Main: Peter Lang, 1990.

KOSSLER, Matthias. Die Philosophie Schopenhauers als Erfahrung des Charakters. In: Dieter Birnbacher; Andreas Lorenz; Leon Miodonski (Ed.). Schopenhauer im Kontext. Deutsch-polnisches Schopenhauer-Symposium 2000. Würzburg: Königshausen \& Neumann, 2002, pp. 91-110.

KOSSLER, Matthias. Empirische Ethik und christliche Moral. Zur Differenz einer areligiösen und einer religiösen Grundlegung der Ethik am Beispiel der Gegenüberstellung Schopenhauers mit Augustinus, der Scholastik und Luther. Würzburg: Königshausen \& Neumann, 1999.

KOSSLER, Matthias. Schopenhauer als Philosoph des Übergangs. In: Marta Kopij; Wojciech Kunicki (Ed.). Nietzsche und Schopenhauer. Rezeptionsphänomene der Wendezeiten. Leipzig: Leipziger Universitäts-Verlag, 2006, pp. 365-379.

KOSSLER, Matthias. Die eine Anschauung - der eine Gedanke. Zur Systemfrage bei Fichte und Schopenhauer. In: Lore Hühn (Ed.). Die Ethik Arthur Schopenhauers im Ausgang vom Deutschen Idealismus (Fichte/Schelling). Würzburg: Ergon, 2006, pp. 349-364.

LEMANSKI, Jens. Christentum im Atheismus. Spuren der mystischen Imitatio Christi-Lehre in der Ethik Schopenhauers, Vol. 2. London: Turnshare, 2011.

LEMANSKI, Jens: The Denial of the Will-to-Live in Schopenhauer's World and his Association of Buddhist and Christian Saints. In: Arati Barua; Michael Gerhard; Matthias Koßler (Ed.). Understanding Schopenhauer through the Prism of Indian Culture. Philosophy, Religion and Sanskrit Literature. Berlin: de Gruyter, 2013, pp. 149-187. 
LEMANSKI, Jens: Schopenhauer's World: The System of The World as Will and Presentation I. Schopenhaueriana. Revista española de estudios sobre Schopenhauer, v. 2, 2017, pp. 297-315.

MALTER, Rudolf. Der eine Gedanke. Hinführung zur Philosophie Arthur Schopenhauers. Darmstadt: Wissenschaftliche Buchgesellschaft, 2010.

MALTER, Rudolf. Arthur Schopenhauer. Transzendentalphilosophie und Metaphysik des Willens. Stuttgart-Bad Cannstatt: Frommann-Holzboog, 1991.

ROSENZWEIG, Franz. Stern der Erlösung. Frankfurt am Main: Kauffmann, 1921.

SCHOPENHAUER, Arthur. The World as Will and Representation. 2 Vol. Transl. by E.F.J. Payne. Indian Hills (Colorado): Falcon's Wing Press, 1958. [= W I / W II]

SCHOPENHAUER, Arthur. The Two Fundamental Problems of Ethics. Transl. by Christopher Janaway. Cambridge: Cambridge University Press, 2009. [= E]

SCHOPENHAUER, Arthur. Parerga and Paralipomena. Short Philosophical Essays. Vol. 2. Transl. by Adrian Del Caro and Christopher Janaway. Cambridge: Cambridge University Press, 2015. [= P II]

SCHOPENHAUER, Arthur: Philosophische Vorlesungen. 1. Teil: Theorie des gesammten Vorstellens, Denkens und Erkennens. Ed. by Volker Spierling. München: Piper, 1986. [= VN I]

SCHOPENHAUER, Arthur: Philosophische Vorlesungen. 4. Teil: Metaphysik der Sitten. Hrsg. v. Volker Spierling. München: Piper, 1985. [= VN IV]

SCHOPENHAUER, Arthur: Der handschriftliche Nachlaß. Band 1: Frühe Manuskripte (18041818). Ed. by Arthur Hübscher. München: dtv, 1985. [= HN I]

SCHUBBE, Daniel. Philosophie des Zwischen. Hermeneutik und Aporetik bei Schopenhauer. Würzburg: Königshausen \& Neumann, 2010.

SCHUBBE, Daniel. Formen der (Er-)Kenntnis. Ein morphologischer Blick auf Schopenhauer. In: Günter Gödde / Michael B. Buchholz (Ed.). Der Besen, mit dem die Hexe fliegt. Wissenschaft und Therapeutik des Unbewussten. Bd. 1: Psychologie als Wissenschaft der Komplementarität. Gießen: Psychosozial-Verlag, 2012, pp. 359-385.

SCHMIDT, Alfred. Die Wahrheit im Gewande der Lüge. Schopenhauers Religionsphilosophie. München: Piper, 1986.

SPIERLING, Volker. Schopenhauers transzendentalidealistisches Selbstmißverständnis. Prolegomena zu einer vergessenen Dialektik. Diss. München 1977.

SPIERLING, Volker. Die Drehwende der Moderne. Schopenhauer zwischen Skeptizismus und Dogmatismus. In: Volker Spierling (Ed.). Materialien zu Schopenhauers "Die Welt als Wille und Vorstellung”. Frankfurt am Main: Suhrkamp, 1984, pp. 14-83.

SPIERLING, Volker. Arthur Schopenhauer. Eine Einführung in Leben und Werk. Leipzig: Reclam, 1998.

STRUB, Christian. Weltzusammenhänge. Kettenkonzepte in der europäischen Philosophie. Würzburg: Königshausen \& Neumann, 2011.

WEIMER, Wolfang. Ist eine Deutung der Welt als Wille und Vorstellung heute noch möglich? Schopenhauer-Jahrbuch, Würzburg, v. 76, 1995, pp. 11-51.

WILHELM, Karl Werner. Zwischen Allwissenheitslehre und Verzweiflung. Der Ort der Religion in der Philosophie Schopenhauers. Hildesheim: Olms, 1994.

ZINT, Hans. Das Religiöse bei Schopenhauer. Jahrbuch der Schopenhauer-Gesellschaft, Frankfurt a.M., v. 17, 1930, pp. 3-76. 